\title{
In vitro effect of UV-C irradiation on Guignardia citricarpa and on postharvest control of citrus black spot
}

\author{
Maria C. Canale ${ }^{1}$, Eliane A. Benato² ${ }^{2}$ Patrícia Cia $^{3}$, Marineia L. Haddad ${ }^{4}$ \& Sérgio F. Pascholati ${ }^{1}$ \\ ${ }^{1}$ Departamento de Entomologia, Fitopatologia e Zoologia Agrícola, Universidade de São Paulo, ESALQ, 13418-900, \\ Piracicaba, SP, Brazil, ${ }^{2}$ Instituto de Tecnologia de Alimentos, 13070-178, Campinas, SP, Brazil; ${ }^{3}$ Instituto Agronômico, \\ 13201-970, Jundiaí, SP, Brazil; ${ }^{4}$ Departamento de Entomologia, Fitopatologia e Zoologia Agrícola, Universidade de São \\ Paulo, ESALQ, 13418-900, Piracicaba, SP, Brazil
}

Author for correspondence: Maria Cristina Canale, e-mail: cristina_canale@hotmail.com

\begin{abstract}
Black spot, caused by Guignardia citricarpa, is one of the main diseases affecting citrus fruits. UV-C irradiation is known to have potential to be used as an alternative method to supplement or replace the use of fungicides, especially because it promotes resistance against pathogens. The aim of this work was to evaluate the in vitro effects of UV-C irradiation on G. citricarpa development and on the control of black spot in postharvest orange. Additionally, changes in skin color of the fruit as a result of UV-C treatment were evaluated. Mycelial growth, conidial germination and appressoria formation were evaluated in vitro after fungal exposure to different irradiation doses. Also, 'Valência' oranges naturally infected were submitted to different irradiation doses to check the possibility of in vivo control. Fruit were stored at $25^{\circ} \mathrm{C} / 80 \% \mathrm{RH}$ and evaluated 3, 7, 10 and 14 days after treatment and area under the disease progress curve was calculated. UV-C irradiation affected conidial germination of G. citricarpa and apressorium formation. UV-C irradiation was not able to control citrus black spot on fruit at a satisfactory level; however, incidence of quiescent black spot lesions was lower on postharvest 'Valência' orange treated with 7.28 and $15.66 \mathrm{~kJ} \mathrm{~m}^{-2}$. Low UV-C doses did not affect the visual aspect of fruit. Thus, UV-C irradiation can contribute for the reduction of postharvest losses caused by citrus black spot and reduce the use or doses of fungicides on disease control.
\end{abstract}

Key words: Citrus sinensis, conidia, mycelium, peel color, physical control.

\section{RESUMO}

Efeito in vitro da irradiação UV-C sobre Guignardia citricarpa e no controle pós-colheita da pinta preta dos citros

A pinta preta, causada por Guignardia citricarpa, é uma das principais doenças que afetam frutos cítricos. A irradiação UV-C tem potencial para ser utilizada como método alternativo para suplementar ou substituir o uso de fungicidas, especialmente por promover resistência contra patógenos. O objetivo deste trabalho foi avaliar os efeitos da irradiação UV-C sobre o desenvolvimento in vitro de $G$. citricarpa e no controle da pinta preta em laranja pós-colheita. Adicionalmente, foram avaliadas as alterações na cor da casca dos frutos. Crescimento micelial, germinação de conídios e formação de apressórios foram avaliados in vitro após a exposição do fungo a diferentes doses de irradiação. Frutos de laranja 'Valência' naturalmente infectados foram submetidos a diferentes doses de irradiação (0,52; 1,04; 3,$13 ; 7,28 ; 15,66$ e $31,20 \mathrm{~kJ} \mathrm{~m}^{-2}$ ) para verificar a possibilidade de controle in vivo. Os frutos foram armazenados a $25^{\circ} \mathrm{C} / 80 \% \mathrm{UR}$ e avaliados 3, 7, 10 e 14 dias após o tratamento e a área abaixo da curva de progresso da doença foi calculada. A exposição à UV-C afetou a germinação de conídios de G. citricarpa e a formação de apressórios. A irradiação com UV-C não foi capaz de controlar a pinta preta de maneira satisfatória; no entanto, a incidência de lesões de pinta preta quiescentes foi menor em laranjas 'Valência' tratadas em pós-colheita com 7,28 e 15,66 kJ m². Doses baixas de UV-C não afetaram o aspecto visual dos frutos. Portanto, a irradiação UV-C pode contribuir para a redução de perdas pós-colheita causadas pela pinta preta dos citros e reduzir o uso ou as doses de fungicidas no controle desta doença. Palavras-chave: Citrus sinensis, conídios, controle físico, cor da casca, micélio.

\section{INTRODUCTION}

Brazil is the main producer of citrus fruits and the main exporter of orange juice in the world. In Brazil this crop faces several phytosanitary problems and among them is citrus black spot, caused by Guignardia citricarpa Kiely [anamorph Phyllosticta citricarpa (McAlpine) Aa] (Reis et al., 2006). The infection by G. citricarpa can occur in the early stages of fruit maturation (Goes et al., 2000). Such infections can remain quiescent without fruits showing symptoms until late. Lesions can appear in postharvest during transport or storage and often at end destination; in case of exported fruits, this may result in rejection of the merchandize. Fruits bearing symptoms are unsuitable for the fresh fruit market because of their appearance. The pathogen is classified as a harmful exotic organism in the European Community and rated as an A1 quarantine disease (EFSA, 2008).

On postharvest, fungicides such as benzimidazol and imazalil may be used in the disease control (Fischer et al., 2004), but the disease problem has worsened because of the development of fungicide resistance. The issue 
is complicated by the fact that demand for fruits free of chemical residues by costumers is on the rise (Cia et al., 2007) hence alternative control strategies such as physical treatments are becoming attractive options.

Numerous studies have demonstrated the effectiveness of ultraviolet-C radiation (190-280 nm wavelength) in reducing fruits and vegetable deterioration, as a good sanitation method that does not leave residues on the product, additionally it is a low cost option that is easily applied (Rivera-Pastrana et al., 2007). UV-C was efficient for controlling postharvest diseases of citrus fruits and there are evidences to support the possibility for controlling quiescent infections by using UV-C radiation at postharvest (Stevens et al. 1996, 1998).

UV-C at low doses $\left(0.25-8.0 \mathrm{~kJ} \mathrm{~m}^{-2}\right)$ has been used as a germicidal agent because it generates harmful mutations on microorganisms and, additionally, the phenomenon of resistance induction in fruits and vegetable by UV-C has been frequently reported (Wilson et al., 1994; Terry \& Joyce, 2004; Rivera-Pastrana et al., 2007). In vitro studies revealed that UV-C irradiation delays and decreases germination and mycelial growth of Botrytis cinerea and doses of 0.84 $\mathrm{kJ} \mathrm{m}^{-2}$ or higher exhibits germicidal effect on conidia, but not on the mycelium (Camili et al., 2004). The germicidal effect on pathogens was also observed when $B$. cinerea and Monilinia fructigena conidia were inactivated by UV-C (Marquenie et al., 2002). UV-C irradiation was also shown to increase the accumulation of phytoalexins (scoparone and scopoletin) in fruits having an adverse effect on the fruit rot pathogen Penicillium digitatum (Rodov et al., 1994; Ryalls et al., 1996) and inducing phenylalanine ammonia-liase and peroxidase activities in grapefruit (Droby et al., 1993).

UV-C hormesis is described as the use of potentially harmful irradiation at low doses in order to induce a beneficial stress response on hosts (Shama \& Alderson, 2005). Hormetic doses of UV-C have been studied as a treatment to extend postharvest life of fruit and vegetable and for its ability to activate disease resistance (Charles \& Arul, 2007). However, visible damage on fruits caused by exposure to high UV-C doses has been reported for citrus (Ben-Yehoshua et al., 1998), bell peppers (Mercier et al., 2001) and also bananas, on which severe brown discoloration of peel tissue may result from that treatment (Terry \& Joyce, 2004). Thus, it is necessary to carefully adjust the doses applied to each kind of fruit to prevent undesirable reactions such as softening and/or skin browning (Cia et al., 2007).

In case beneficial effects for postharvest management of oranges, as evaluated in the present study, are proven, germicidal ultraviolet light may then become an attractive option for use in the packinghouses, prior to fruit classification, for controlling postharvest orange diseases. The aim of this work was to evaluate the effect of UV-C irradiation on in vitro mycelial growth, conidial germination and appressoria formation by G. citricarpa and on the postharvest control of citrus black spot of 'Valência' orange.

\section{MATERIAL AND METHODS}

\section{In vitro effect of $\mathrm{UV}-\mathrm{C}$ irradiation on $G$. citricarpa development}

Guignardia citricarpa was isolated from injured tissue fragments of 'Valência' oranges, collected in an orchard with high incidence of citrus black spot at Mogi Guaçu, state of São Paulo, Brazil. These fragments were submitted to disinfestation and then transferred to potatodextrose agar (PDA) medium in Petri dishes until the onset of colonies. Colony fragments were then transferred to new PDA plates and maintained in an incubator at $25^{\circ} \mathrm{C} / 12 \mathrm{~h}$ light regime.

The effect of different UV-C irradiation doses on mycelial growth was evaluated by transferring $3 \mathrm{~mm}$ diam mycelium discs from approximately 3 weeks age colony. Mycelium discs, all taken from the same colony, were transferred to the center of PDA in Petri dishes $\left(\right.$ Pyrex $^{\circledR}$, USA, $10 \times 1.5 \mathrm{~cm}$ ), one disc each plate. The plates were maintained at $25^{\circ} \mathrm{C}$ for $7 \mathrm{~h}$ to provide some mycelium development before exposition to irradiation. Exposure regimes to UV-C doses of $0.52 ; 1.04 ; 3.13 ; 10.44$ and 15.66 $\mathrm{kJ} \mathrm{m}^{-2}$ were determined based upon the length of exposition under a fixed fluency rate of $1.74 \mathrm{~mW} \mathrm{~cm} \mathrm{~cm}^{-2}$ provided by lamps having a wavelength peak at $254 \mathrm{~nm}(2.5 \mathrm{~cm} \times 88$ $\mathrm{cm}, 30 \mathrm{~W}$, Yaming Lighting, China). The chamber used for UV-C treatment had four germicidal UV lamps, two at the top of the chamber and two at the bottom, providing homogeneous irradiation of plates. The Petri dishes were exposed without the lids at $10 \mathrm{~cm}$ from the light source; thus, PDA medium in the plates containing G. citricarpa mycelial disc was completely exposed to UV-C irradiation. Plates were immediately closed and sealed to avoid contamination. Non-irradiated plates were used as controls. The plates were maintained at $25^{\circ} \mathrm{C} / 12 \mathrm{~h}$ photoperiod for 21 days and colony diameter was then evaluated every 3 days. The experimental design was completely randomized with five replications (one plate per set).

Influence of UV-C treatment on conidial germination and appressoria formation of G. citricarpa were also evaluated. Sterile polystyrene Petri dishes (Pleion $^{\circledR}$, Barueri, SP, 90 × $1.5 \mathrm{~cm}$ ) were divided into four quadrants and $40 \mu \mathrm{L}$ droplets of a conidial suspension (adjusted to $10^{5}$ conidia $\mathrm{mL}^{-1}$, with the help of a haemocytometer) were deposited into the center of each quadrant of each plate and they were exposed to the same UV-C treatments as described above. Plates were exposed without the lids; there was no evaporation of the droplets whereas exposure time was relatively short. After this, a tuft of cotton moistened with distilled autoclaved water was placed in the plates to avoid evaporation of the droplets. The plates were immediately closed with the lids and sealed. Control plates were not exposed to irradiation. Conidial germination and appressoria formation were evaluated after $24 \mathrm{~h}$ of incubation at $25^{\circ} \mathrm{C} / 12 \mathrm{~h}$ photoperiod. Germination and appressoria 
formation was interrupted by adding a droplet of lactophenol to the suspension of G. citricarpa conidia, which was then covered with a coverslip. A light microscope (Nikon ${ }^{\circledR}$ E200, Japan) was used to examine 100 conidia per droplet. Results were obtained in percentage of germinated conidia and conidia that formed appressoria. The experiment was carried out twice with eight replications (two plates per set).

\section{Effect of UV-C irradiation in the postharvest control of black spot}

'Valência' oranges naturally infected were harvested in Mogi Guaçu (SP, Brazil), at the same orchard mentioned above. Fruit were washed with water plus detergent, and surface-sterilized with sodium hypochlorite $\left(200 \mathrm{mg} \mathrm{L}^{-1}\right)$ for $10 \mathrm{~min}$. The citrus black spots which developed when fruits were still in the orchard were marked with a pen before treatments in order to allow for the recognition of newly formed lesions that appeared during postharvest. The fruit were irradiated with one of each of the following UV-C doses representing the treatments: $0.52 ; 1.04 ; 3.13 ; 7.28$; 15.66 and $31.20 \mathrm{~kJ} \mathrm{~m}^{-2}$. Such doses were determined based upon the exposition time under a fixed fluency rate of 1.74 $\mathrm{mW} \mathrm{cm} \mathrm{cm}^{-2}$ as previously described. The UV chamber lamps provided homogeneous fruit irradiation, where orange were placed at $10 \mathrm{~cm}$ of distance from the light source. Irradiated and control fruit were placed on corrugated paper boards and kept in the dark $\left(25^{\circ} \mathrm{C} \pm 1^{\circ} \mathrm{C} / 75-85 \% \mathrm{RH}\right)$ in order to minimize the photoreversibility process (Stevens et al., 1998). Evaluations of incidence of new black spot lesions were carried out after 3, 7, 10 and 14 days of storage. Incidence of quiescent black spot lesions was calculated based upon the area under the disease progress curve (AUDPC), according to the equation: AUDPC $=\sum\left[\left(y_{i}+\right.\right.$ $\left.\left.y_{i+1}\right) / 2 \times\left(t_{i+1}-t_{i}\right)\right]$, where $y_{i}$ is the incidence at time $t_{i}$, in days, and $y_{i+1}$ is the incidence at time $t_{i+1}$ (De Capdeville et al., 2002). The experiment was carried out twice involving 40 fruit per treatment.

\section{Orange peel color analysis}

Color of orange peel was evaluated immediately upon arrival from the field and after the treatments storage period (see details above). The color of ten fruit was determined by using a Minolta Chroma Meter, model CR300, based upon the parameters $L^{*}$ (luminosity), $a^{*}$ (green to red) and $b^{*}$ (blue to yellow) at three points, on the day of harvesting and at the end of storage period.

\section{Statistical analysis}

The experimental design was completely randomized in all experiments. Statistical significance was determined by using analysis of variance and Tukey test for in vitro experiments and skin color analysis. Regression analyses were carried out for in vivo test and whenever required. All statistical analysis was performed using SAS 9.2 TS (SAS Institute 2008).

\section{RESULTS}

\section{In vitro effect of UV-C irradiation on G. citricarpa development}

The doses of 3.13 and $15.66 \mathrm{~kJ} \mathrm{~m}^{-2}$ significantly reduced the mycelial growth of G. citricarpa (Table 1); however, no treatment resulted in complete inhibition of fungal growth. No fungal growth was noticeable for any treatment after three days of incubation, regardless of irradiation dose. Colonies were still very small and cottony after six days of incubation without any visible difference between UV-C treatments but, in contrast, fungal colonies in control were already melanized (data not shown). In the following evaluations the colonies in UV-C treatments had already recovered and were developing normally and had an appearance equivalent to that of control. In addition, regression analysis between the mycelial growth index calculated according to Peres et al. (2003) and UV-C doses did not show a correlation (data not shown), indicating that UV-C do not significantly influence G. citricarpa mycelial growth.

The germination and appressoria formation were remarkably reduced by UV-C doses during the incubation period (Table 1). Statistical analysis showed that the UV-C have a significant effect both on conidial germination and appressorium formation by germinated conidia. Conidial morphology was not affected by the radiation (data not

TABLE 1 - Effect of different UV-C doses on in vitro development of Guignardia citricarpa at $25^{\circ} \mathrm{C}$

\begin{tabular}{lccc}
\hline \hline UV-C Doses & Mycelial Growth & Germination & Apressorium \\
\cline { 3 - 4 } $\mathbf{k J ~ m}^{-\mathbf{2}}$ & $\mathbf{c m}^{\mathbf{x}}$ & & $\mathbf{\%}^{\mathbf{y}}$ \\
\hline 0 & $2.42 \mathrm{a}$ & $20.33 \mathrm{a}$ & $6.5 \mathrm{a}$ \\
0.52 & $2.41 \mathrm{a}$ & $9.16 \mathrm{~b}$ & $3.66 \mathrm{a}$ \\
1.04 & $2.46 \mathrm{a}$ & $2.66 \mathrm{c}$ & $0.16 \mathrm{~b}$ \\
3.13 & $2.06 \mathrm{~b}$ & $3.00 \mathrm{c}$ & $0.83 \mathrm{~b}$ \\
10.44 & $2.56 \mathrm{a}$ & $2.50 \mathrm{c}$ & $0.16 \mathrm{~b}$ \\
15.66 & $1.93 \mathrm{~b}$ & $1.00 \mathrm{c}$ & $1.00 \mathrm{~b}$ \\
CV $(\%)$ & 4.07 & 4.30 & 4.30 \\
\hline
\end{tabular}

\footnotetext{
${ }^{x}$ Mean of 35 repetitions, evaluated every 3 days until 21 days of incubation. ${ }^{y}$ Mean of 6 repetitions, evaluated after $24 \mathrm{~h}$ of incubation. Means
} followed by the same letters in the column are not significantly different from each other by Tukey test $(P=0.05)$. 
shown). Thus, results of the experiment involving the evaluation of the effect of UV-C radiation on G. citricarpa have shown that this treatment, although being deleterious to the fungus at germination and infection stages is not lethal to its colonies.

\section{Effect of UV-C irradiation the postharvest control of black spot}

The third degree polynomial regression best fit the AUDPC of black spot incidence data and showed a significant correlation between UV-C dose and AUDPC (Figure 1). The 7.28 and $15.66 \mathrm{~kJ} \mathrm{~m}^{-2}$ irradiation doses were more effective in delaying the appearance of new black spot lesions on orange at postharvest. Additionally, results have indicated that new lesions developed at lower rates for these two doses, that is, the rate of appearance of new lesions was slower (data not shown). Even though quiescent lesions may still appear after UV-C radiation treatment, UV-C can contribute for reduction of postharvest incidence of quiescent black spot lesions in 'Valência' oranges during postharvest storage.

\section{Orange peel color analysis}

The evaluation of peel color of fruit submitted to UV-C treatments showed that $L^{*}$ (luminosity) values decreased as irradiation dose increased as compared to non-irradiated control fruit and the parameter values $a^{*}$ increased and $b^{*}$ decreased when the doses were higher (Table 2). This means that UV-C can alter the color of orange peel. There were statistical differences among the doses for the parameters $L^{*}$ and $b^{*}$, and treatment with 1.04 and $3.13 \mathrm{~kJ} \mathrm{~m}^{-2}$ were not different from the control and they did not affected the appearance of the fruit. It was observed that fruit both in control and treated with low UV-C doses had a good yellow appearance whereas orange treated with higher UV-C doses became darker and senescent.

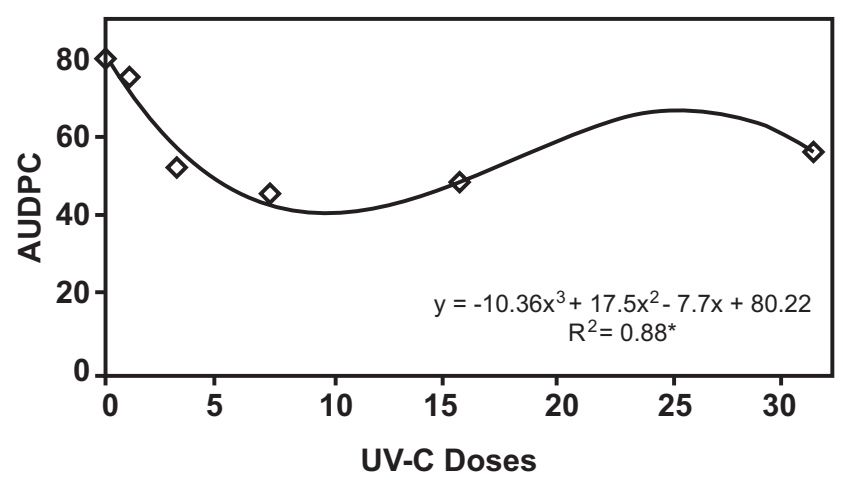

FIGURE 1 - Area under the disease progress curve (AUDPC) for incidence of new black spot lesions on 'Valência' orange. Fruit naturally infected by Guignardia citricarpa were submitted to different UV-C doses and stored for 14 days at $25^{\circ} \mathrm{C} / 80 \% \mathrm{RH}$. *significant at $7 \%$.

\section{DISCUSSION}

Results obtained during the present work have shown that the UV-C irradiation does not inhibit the mycelial growth of $G$. citricarpa in vitro, but inhibits its conidial germination and appressoria formation. Similarly, Camili et al. (2004) reported that application of UV-C on Botrytis cinerea delayed and decreased the germination and doses equal or higher than $0.84 \mathrm{~kJ} \mathrm{~m}^{-2}$ killed its conidia but were not lethal to the mycelia. Another study has shown that doses equal to or higher than $0.4 \mathrm{~kJ} \mathrm{~m}^{-2}$ were capable of killing conidia Colletotrichum gloeosporioides (Cia et al., 2007). These results indicate that, for fungi in general, spores and germ tubes may be more susceptible to UV-C radiation than the mycelium. In the case of $G$. citricarpa our results have shown that UV irradiation may not exert a lethal effect on mycelium and conidia but lead to a delay in germination. This effect may be linked to the observed delay and reduction on the incidence of quiescent black spot lesions caused by G. citricarpa on 'Valência' oranges.

UV-C treatment led to a slowing in the pace of development of quiescent black spot lesions on orange fruit naturally infected by $G$. citricarpa, but did not interrupt or prevent the emergence of new lesions. Spores and mycelium of $G$. citricarpa probably remained viable in wounds or inside infected tissue and survived the UV-C treatment since UV-C irradiation does not penetrate the plant tissues well. Similar results have been obtained for the use of UV-C treatments in other postharvest diseases in grapes (Camili et al., 2004) and papaya (Cia et al., 2007). It is likely that the reduction of development of new lesions observed in our study was caused by resistance induction provoked in the orange fruit by UV-C irradiation. Resistance induction against Penicillium sp. in citrus fruits resulting from postharvest UV-C treatment was observed by Ben-Yehoshua et al. (1992). The best results of control of citrus black spot obtained in this study were yielded for treatments involving a dose of $7.28 \mathrm{~kJ} \mathrm{~m}^{-2}$. Stevens et al. (1998) observed a hormetic effect of $7.5 \mathrm{~kJ} \mathrm{~m}^{-2} \mathrm{UV}-\mathrm{C}$ dose that led to control of latent brown rot, caused by Monilinia fructicola, on peaches. When UV-C doses were above the optimum, the resistance of peach fruit to brown rot decreased. This suggests the involvement of a hormetic effect, which is defined as a stimulation of a beneficial plant response by low or sublethal doses of an agent (Stevens et al, 1998; Shama \& Alderson, 2005). This may also explain the tendency of increased incidence of new black spot lesions at higher doses UV-C in our study $\left(31.20 \mathrm{~kJ} \mathrm{~m}^{-2}\right)$. This was also reported by Barka et al. (2000) for tomato fruit treated with a hormetic UV-C dose $3.7 \mathrm{~kJ} \mathrm{~m}^{-2}$ which led to a delay of the cell wall degradation and consequent retardation of the softening of tissues.

In the present work, the higher UV-C doses caused browning of fruit peel and early senescence. Color alteration such as blemishes and discoloration of fruit peel were reported in association with exposition to high UV-C 
M.C. Canale et al.

TABLE 2 - Peel color of 'Valência' orange irradiated with different doses of UV-C, stored for 14 days at $25^{\circ} \mathrm{C} / 80 \% \mathrm{RH}$

\begin{tabular}{lccc}
\hline \hline UV-C Doses $\left(\mathbf{k J ~ m}^{-\mathbf{2}}\right)$ & $\boldsymbol{L}$ & $\boldsymbol{a}$ & $\boldsymbol{b}$ \\
\hline Harvest day & $\mathbf{6 9 . 3 6}$ & $\mathbf{- 5 . 0 3}$ & $\mathbf{7 3 . 3 8}$ \\
\hline 0 & $72.54 \mathrm{a}$ & $-2.59 \mathrm{a}$ & $79.73 \mathrm{a}$ \\
1.04 & $72.67 \mathrm{a}$ & $-1.07 \mathrm{a}$ & $79.25 \mathrm{a}$ \\
3.13 & $69.99 \mathrm{ab}$ & $-0.65 \mathrm{a}$ & $75.31 \mathrm{ab}$ \\
7.28 & $68.58 \mathrm{~b}$ & $-0.43 \mathrm{a}$ & $73.57 \mathrm{~b}$ \\
15.66 & $67.69 \mathrm{~b}$ & $1.34 \mathrm{a}$ & $72.59 \mathrm{~b}$ \\
31.2 & $67.14 \mathrm{~b}$ & $2.32 \mathrm{a}$ & $72.09 \mathrm{~b}$ \\
C.V. $(\%)$ & 3.25 & nd* & 5.52 \\
\hline
\end{tabular}

On Minolta colorimeter, $L^{*} a^{*} b^{*}$ system, where $L^{*}$ stands for luminosity $\left(0=\right.$ black to $100=$ white), $a^{*}$ and $b^{*}$ chroma $\left(\mathrm{a}^{-}=\right.$green to $\mathrm{a}^{+}=\mathrm{red}$ and $\mathrm{b}=$ blue to $\mathrm{b}^{+}=$yellow). Mean of ten fruits per treatment. Means followed by the same letters in the column are not significantly different from each other by the Tukey's test $(P=0.05)$.

nd* Not determined.

doses (Rivera-Pastrana et al., 2007). Ben-Yehoshua et al. (1998) observed that an abiotic stress produced by high doses of UV-C irradiation exerted visible damage to the peel of citrus fruit and Camili et al. (2005) also observed browning on grapes exposed to UV-C irradiation. The doses beyond the threshold of those required for the best level of Penicillium digitatum control in grapefruits resulted in high infection and peel blemishes (Droby et al., 1993). The occurrence of brown lesions on postharvest products is suggested to be due to the accumulation of phenolic compounds that are known to be induced by UV-C (Glaßgen et al., 1998; Erkan et al., 2001). In our experiment, low UV-C doses did not cause discoloration in 'Valência' orange peel. It is known that other sensorial features (aroma and flavor) of vegetables are not altered by low UV-C doses (Rivera-Pastrana et al., 2007).

In summary, UV-C had no fungicidal effect on Guignardia citricarpa but the radiation affected conidial germination and appressoria formation in vitro. Although the in vivo levels of control of citrus black spot that were achieved with the UV-C treatments which were tested were not regarded as satisfactory, low UV-C doses decreased the incidence of new black spot lesions in oranges in postharvet without affecting the appearance of fruit peel. Adittional studies are needed to determine the lowest UV-C dose required to achieve adequate levels of postharvest control of black spot. In case such a condition is determined, physical treatment with UV-C may become a reasonable alternative to complement fungicide treatments and reduce the use or doses of fungicides for postharvest orange treatment. Additionally, exposure to UV-C radiation is a safe physical treatment that does not leave residues in the fruits.

\section{ACKNOWLEDGEMENTS}

The authors thank the Fundação de Apoio à Pesquisa do Estado de São Paulo - FAPESP and Conselho Nacional de Desenvolvimento Científico e Tecnológico - CNPq for financial support.

\section{REFERENCES}

Barka EA, Kalantari S, Makhlouf J, Arul J (2000) Impact of UV-C irradiation on the cell wall-degrading enzymes during ripening of tomato (Lycopersicon esculentum L.) fruit. Journal of Agricultural and Food Chemistry 48:67-671.

Ben-Yehoshua S, Rodov V, Kim JJ, Carmeli S (1992) Preformed and induced antifungal materials of citrus fruits in relation to the enhancement of decay resistance by heat and ultraviolet treatments. Journal of Agricultural and Food Chemistry 40:1217-1221.

Camili EC, Cia P, Benato EA (2005) Indução de resistência contra doenças pós-colheita. In: Cavalcanti LS, Di Piero RM, Cia P, Pascholati SF, De Resende MLV, Romeiro RS (Eds.) Indução de resistência em plantas a patógenos e insetos. Piracicaba SP. FEALQ. pp. 195-218.

Camili EC, Benato EA, Pascholati SF, Cia P (2004) Avaliação de irradiação UV-C aplicada em pós-colheita na proteção de uva 'Itália' contra Botrytis cinerea. Summa Phytopathologica 30:306-313.

Charles MT, Arul J (2007) UV treatment of fresh fruits and vegetables for improved quality: A status report. Stewart Postharvest Review 3:1-8.

De Capdeville G, Wilson CL, Beer SV, Aist JR (2002) Alternative disease control agents induce resistance to blue mold in harvest 'Red Delicious' apple fruit. Phytopathology 92:900-373.

Cia P, Pascholati SF, Benato EA, Camili EC, Santos CA (2007) Effects of gamma and UV-C irradiation on the postharvest control of papaya anthracnose. Postharvest Biology and Technology 43:366-373.

D'Ahallewin G, Schirra M, Manueddu E, Piga A, Ben-Yehoshua S (1999) Scoparone and scopoletin accumulation and ultraviolet-C induced resistance to postharvest decay in oranges as influenced by harvest date. Journal of the American Society for Horticultural Science 124:702-707.

Droby S, Chalutz E, Horev B, Cohen L, Gaba V, Wilson CL, Wisniewski M (1993) Factors affecting UV-induced resistance in grapefruit against the green mold decay caused by Penicillium digitatum. Plant Pathology 42:418-424.

EFSA (2008) Pest risk assessment and additional evidence provided by South Africa on Guignardia citricarpa Kiely, citrus black spot fungus - CBS. European Food Safety Authority Journal 925:1-4. 
Erkan M, Wang CY, Krizek DT (2001) UV-C irradiation reduces microbial populations and deterioration in Cucurbita pepo fruit tissue. Environmental and Experimental Botany 45:1-9.

Fischer IH, Spósito MB, Lourenço SA, Amorim L (2004) Eficiência dos fungicidas thiabendazole + imazalil, aplicados previamente ou em mistura à cera, no controle do bolor verde em citros. In: I Workshop Internacional de Pós-colheita de Frutas e do II Workshop Internacional de Pós-colheita de Citros, 2004, Cordeirópolis. Brazilian Journal of Plant Physiology, 16:22-22.

Glaßgen WE, Rose A, Madlung J, Koch W, Gleitz J, Seitz HU (1998) Regulation of enzymes involved in anthocyanin biosynthesis in carrot cell cultures in response to treatment with ultraviolet light and fungal elicitors. Planta 204:490-498.

Goes A, Baldassari RB, Feichtenberger E, Spósito MB, AguilarVildoso CI (2000) Cracked spot, a new symptom of citrus black spot (Guignardia citricarpa) in Brazil. In: International Society of Citriculture, Programs and Abstracts 9:145.

Marquenie D, Lammertyn AH, Geeraerd AH, Soontjens C, Van Impe JF, Nicolai BM, Michiels CW (2002) Inactivation of conidia of Botrytis cinerea and Monilinia fructigena using UV-C and heat treatment. International Journal of Food Microbiology 74:27-35.

Mercier J, Baka M, Reddy B, Corcuff R, Arul J (2001) Shortwave ultraviolet irradiation for control of decay caused by Botrytis cinerea in bell pepper: induced resistance and germicidal effects. Journal of the American Society for Horticultural Science 126:128133.

Peres AP, Silva-Mann R, Vieira MDG, Machado JDC (2003) Variabilidade morfocultural e genética de fungos associados à podridão peduncular do mamão. Ciência e Agrotecnologia 27:1053-1062.

Reis RF, Timmer LW, Góes A (2006) Effect of temperature, leaf wetness, and rainfall on the production of Guignardia citricarpa ascospores and on black spot severity on sweet orange. Fitopatologia Brasileira 31:29-34.

Rivera-Pastrana DM, Béjar AAG, Martínes-Telles MA, RiveraDomínguez M, Gonzalés-Aguilar GA (2007) Postharvest biochemical effects of UV-C irradiation on fruit and vegetables. Revista Fitotecnia Mexicana 30:361-372.

Rodov V, Ben-Yehoshua S, Fang D, D'Hallewin G, Castia T (1994) Accumulation of phytoalexins scoparone and scopoletin in citrus fruits subjected to various postharvest treatments. Acta Horticulturae 381:517-525.

Ryalls JA, Neuenschwander UH, Willits MG, Molina A, Steiner HY, Hunt MD (1996) Systemic acquired resistance. Plant Cell 8:1809-1819.

Shama G, Alderson P (2005) UV hormesis in fruits: a concept ripe for commercialization. Trends in Food Science and Technology $16: 128-136$.

Stevens C, Khan VA, Lu JY, Wilson CL, Pusey PL, Kabwe MK, Igwegbe ECK, Chalutz E, Droby S (1998). The germicidal and hormetic effects of UV-C light on reducing brown rot disease and yeast microflora of peaches. Crop Protection 17:75-84.

Stevens C, Wilson CL, Lu JY, Khan VA, Chalutz E, Droby S, Kabwe MK, Haung Z, Adeyeye O, Pusey LP, Wisniewski ME, West M (1996) Plant hormesis induced by ultraviolet light $C$ for controlling postharvest disease of tree fruits. Crop Protection $15: 129-134$.

Terry LA, Joyce DC (2004) Elicitors of induced disease resistance in postharvest horticultural crops: A brief review. Postharvest Biology and Technology 32:1-13.

Wilson CL, El Ghaouth A, Chalutz E, Droby S, Stevens C, Lu JY, Khan V, Arul J (1994) Potential of induced resistance to control postharvest diseases of fruit and vegetables. Plant Disease 78:837843.

TPP 186 - Received 30 September 2010 - Accepted 6 January 2012 Section Editor: Francisco F. Laranjeira 